\title{
Risk assessment for canine leishmaniasis spreading in the north of Italy
}

\author{
Giulia Morosetti', Gioia Bongiorno², Bernadett Beran³, Aldo Scalone², Judith Moser ${ }^{1}$, \\ Marina Gramiccia ${ }^{2}$, Luigi Gradoni², Michele Maroli² \\ ${ }^{1}$ Veterinary Services of Bolzano, Health Department of South Tyrol, Italy; ${ }^{2}$ Section of Vector-Borne \\ Diseases and International Health, MIPI Department, Istituto Superiore di Sanità, Rome, Italy; \\ ${ }^{3}$ Department of Comparative Tropical Medicine and Parasitology, Ludwig-Maximilians University, \\ Munich, Germany
}

\begin{abstract}
The incidence of zoonotic visceral leishmaniasis has not only been recognized but is, in fact, increasing in territories of northern continental Italy previously regarded as non-endemic. Recent findings of sporadic autochthonous canine infections and the presence of phlebotomine vectors in some provinces of north-eastern Italy have stimulated risk assessment for the spreading of leishmaniasis in the autonomous province of Bolzano-South Tyrol, the northernmost territory of the Italian eastern Alps. In July 2008, 61 phlebotomine sand flies (Diptera, Psychodidae) were caught and identified as Phlebotomus perniciosus and Sergentomyia minuta. This is the first record in South Tyrol of P. perniciosus, the most competent vector of Leishmania infantum in Mediterranean countries. Leishmania serology on local dogs kept in kennels gave negative results, while only imported canine leishmaniasis cases were reported by local veterinarians through a questionnaire survey. Bio-geographic aspects and epidemiological consequences are analyzed in relation with the risk of leishmaniasis introduction into the area.
\end{abstract}

Keywords: Phlebotomus perniciosus, sand flies, Leishmania infantum, canine, leishmaniasis, Italy.

\section{Introduction}

Zoonotic visceral leishmaniasis (VL) caused by the kinetoplastid protozoan Leishmania infantum is endemic in all countries of the Mediterranean basin. Parasites are transmitted to humans by the bite of phlebotomine sand flies, and canines serve as the main reservoir host. Although the overall prevalence of human VL in Italy is relatively low (155 cases notified in 2005 and 113 in 2006) according to the Italian Ministry of Health in 2009, the incidence has been increasing in humans as well

Corresponding author:

Michele Maroli

Istituto Superiore di Sanità

Viale Regina Elena, 299, 00161 Rome, Italy

Tel. +3906 4990 2302; Fax +3906 49903561

E-mail: michele.maroli@iss.it as in dogs in the past two decades, with new foci being recorded within the traditional boundaries of endemic transmission, i.e. coastal peninsular and insular Italy, but also in northern continental regions previously regarded as non-endemic. Starting from the early 1990s, autochthonous foci of canine leishmaniasis (CanL) have been progressively recorded in sub-alpine territories of six regions, namely Piedmont, Valle D'Aosta, Lombardy, Trentino, Friuli-Venezia Giulia and Veneto (Mortarino et al., 2004; Ferroglio et al., 2005; Cassini et al., 2007; Maroli et al., 2008; Mortarino et al., 2008). Sporadic human VL cases have also been recorded in some of these foci (Gabrielli et al., 2001; Capelli et al., 2004).

Major changes appear to have occurred in the phlebotomine fauna of northern continental Italy during the past decades. In the 1965-1974 period, an extensive survey has shown that only 11 out of 
the 164 sites surveyed in the area $(6.7 \%)$ were positive for phlebotomine sand flies meaning that Valle d'Aosta and Lombardy were apparently free from Leishmania vectors at that time (Biocca et al., 1977). With regard to Phlebotomus perniciosus, the main vector in peninsular and insular Italy, only six specimens were found in Piedmont, three in Friuli Venezia-Giulia, and one each in Veneto and Trentino.

A number of entomological surveys conducted since the 1990s (Maroli et al., 1995, 2002, 2006a, 2008; Ferroglio et al., 2000; Ferrarese and Maroli, 2002; Ferrarese et al., 2004; Mortarino et al., 2004, 2008; Natale et al., 2004) have shown that two L. infantum vectors are widespread in northern continental Italy. P. perniciosus has been found at high densities at most collecting sites in hilly and low mountain ranges of six regions; P. neglectus, which was never reconfirmed in northern Italy after its first identification in 1917 (Tonnoir, 1921), was re-collected after 1995 in several subalpine sites of five regions and found abundant in some of them. Hence, evidence that the two VL vectors have increased in density and expanded their geographic range in northern continental Italy is well supported.

Recent surveys carried out in north-eastern Italy revealed discontinuous autochthonous foci of CanL as well as the presence of competent phlebotomine vectors in provinces of Veneto and Friuli regions (Fig. 1). In this paper, we report the data of a survey aimed at monitoring the presence of Leishmania vectors and at investigating the existence of conditions favouring the spread of leishmaniasis in the autonomous province of Bolzano-South Tyrol (APB$\mathrm{ST})$, the northernmost province of the Italian eastern Alps.

The objectives of the study were to investigate the presence of sand flies in the APB-ST territory, to determine whether dogs sheltered in local kennels could have been exposed to L. infantum, as well as finding out about the general awareness among local veterinarians of putative autochthonous or imported CanL.

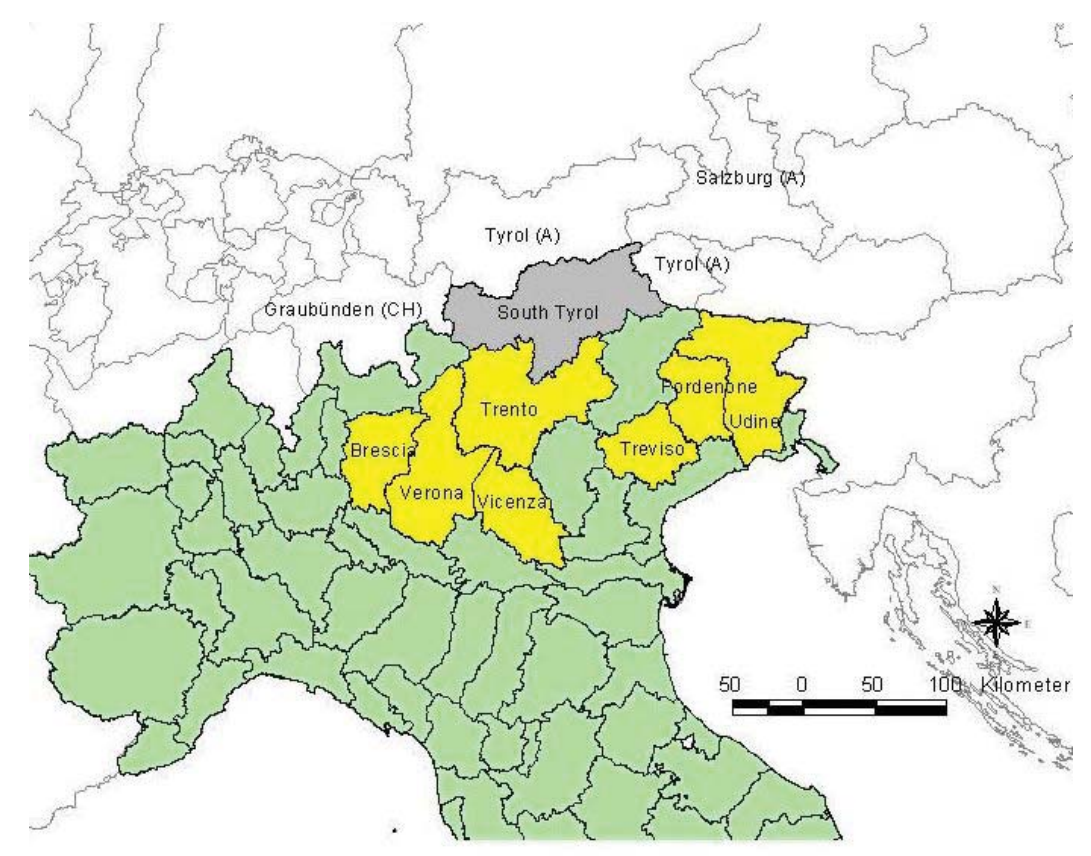

Fig. 1. North-eastern Italian provinces with recent findings of CanL foci and Phlebotomus sand flies (in yellow). The study area is shown in grey. 
Materials and methods

\section{Study area}

APB-ST is located at the northernmost part of Italy. The territory is crossed by the main river Adige and bordered by Austria to the north-east and Switzerland to the west (Fig. 1). It is the largest Italian province with a population of 495,071 inhabitants, a density of 66.8 inhabitants $/ \mathrm{km}^{2}$, in 2008 (Provincial Institute for Statistics; http://www.provinz.bz.it/astat/it/popolazione/442.a sp) and a surface area of $7,400 \mathrm{~km}^{2}$ administratively divided into 116 municipalities. The capital is Bolzano with 101,417 inhabitants. Most of the APB-ST settlements are situated at an altitude of 300 to $1,200 \mathrm{~m}$ above sea level and a large proportion of the territory the altitude between 800 and $1,800 \mathrm{~m}$ is covered by forests and highland pastures. The lower valleys are mostly cultivated (predominantly vineyards and fruit trees) with different types of shrubs and mixed forests. Being on the southern side of the Alps, the climate is milder than in the Austrian and Swiss border areas but colder than the neighbouring Trento province. There are five distinct climate zones: humid subtropical, oceanic, humid continental, sub-arctic, and above 3,000 $\mathrm{m}$ alpine tundra with eternal frost (Climate, 2008).

\section{Entomological survey}

The survey was carried out in 2008 along the valley of the river Adige during two different periods of the sand fly season, namely 16-23 July and 18-22 August. These periods correspond to the estimated peak of sand fly activity in northern continental Italy (Ferroglio et al., 2000; Bongiorno et al., 2003). The entomological survey was restricted to areas having climate, exposition (south or southwest) and environmental variables potentially favourable for the sand fly life cycle (Rioux et al., 1984; Bongiorno et al., 2008; Rossi et al., 2008). It incorporated municipalities (Fig. 2) located in an area starting

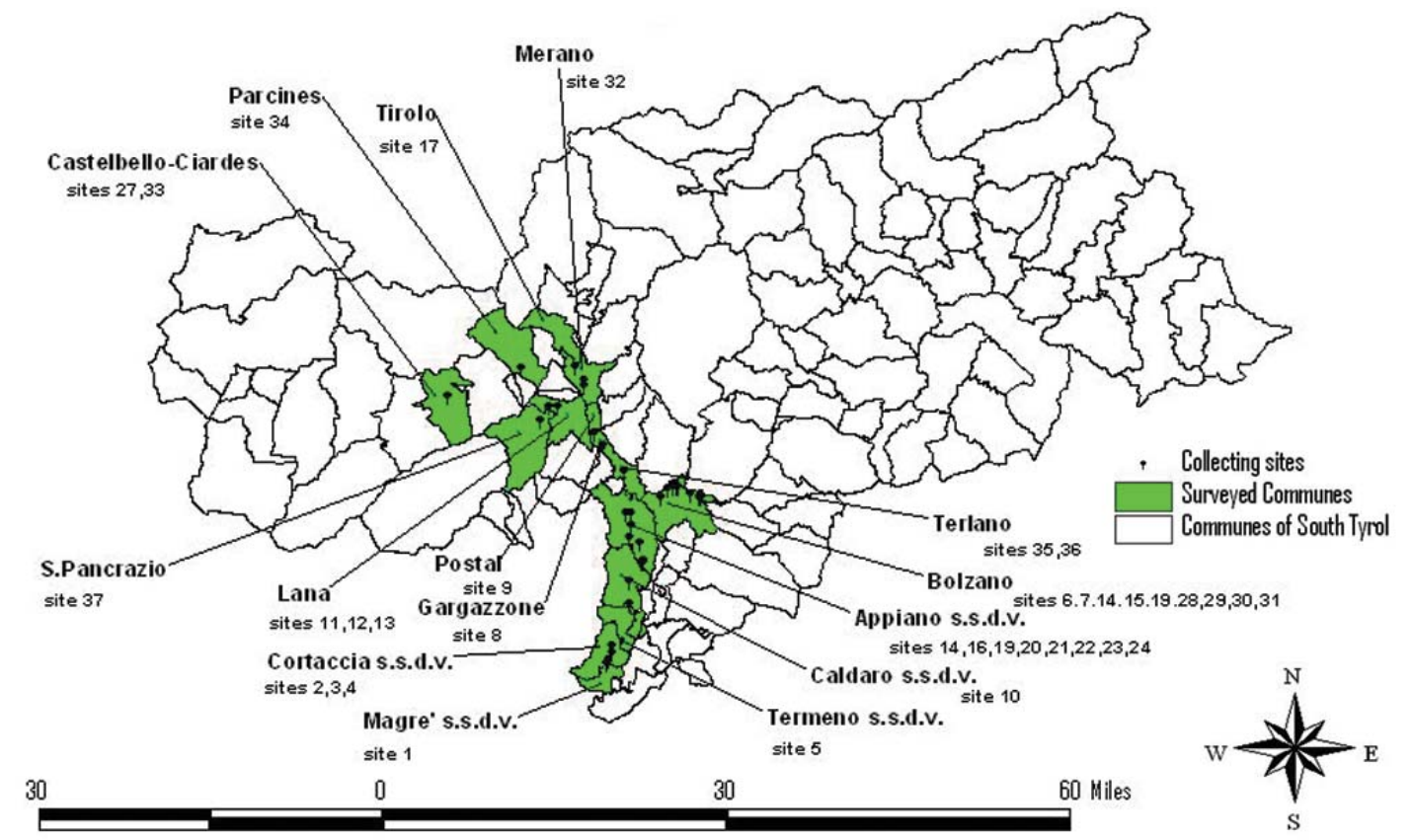

Fig. 2. Map providing the autonomous province of Bolzano-South Tyrol (APB-ST) outlines and the location of the 15 municipalities included in the entomological study. 
A)

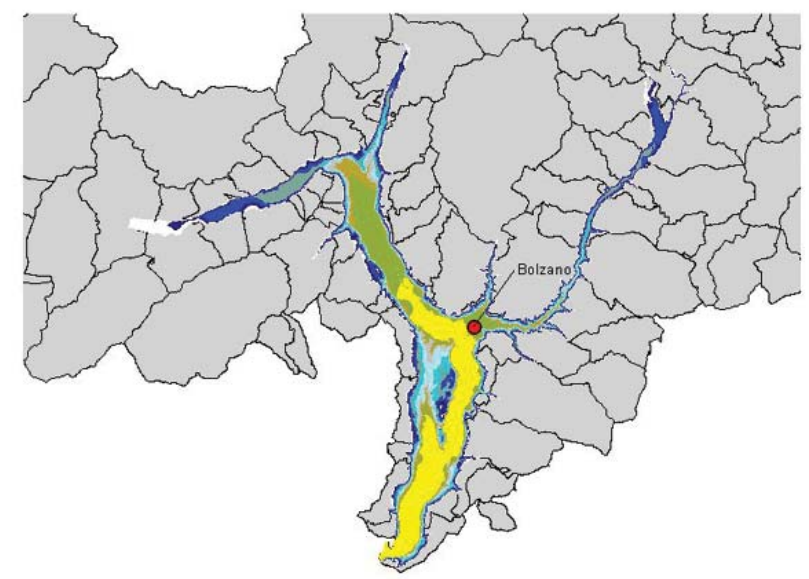

- Main city

Siddtirol altitude lelvels up to $700 \mathrm{~m}$ a.s.l.

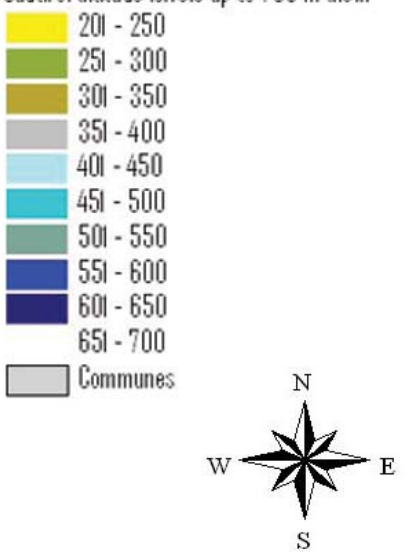

B)

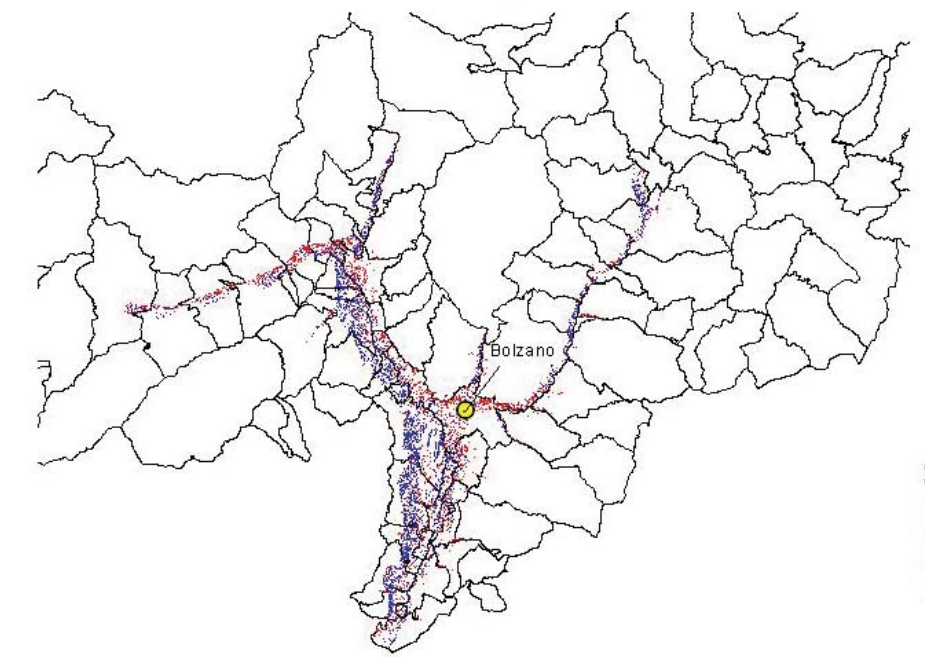

- Main city

Südtirol south-east exposition of sites

East

South

Communes

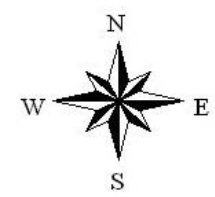

Fig. 3. Adige valley, geographical characteristics of the area: A) altitude; B) exposition. 
from the southernmost village of the lower Adige valley with a southern to south-western exposure, including the town of Bolzano and its surroundings $\left(46.5^{\circ} \mathrm{N}, 11.3^{\circ} \mathrm{E}\right)$, and proceeded northwards along the upper Adige valley up to the town of Merano towards the north-western border with Switzerland. The geographical characteristics of the Adige valley are shown in Fig. 3. Suitable collection sites were mainly chosen in the humid subtropical climate zone of the valley with the driest and sunniest weather, i.e. $24 \mathrm{~h}$ averages in July of about $23^{\circ} \mathrm{C}$ (Climate, 2008), identified by mapping an area separated from the highway passing through the valley, with the aid of geographical information system (GIS) software (ArcView 3.3, ESRI, Redlands, CA, USA) using metadata from the Provincial Forestry Department. In addition, farms in these locations were identified with the help of detailed local maps (Tobacco, $1: 25,000)$ after consulting the veterinary authority.

Records from the collecting sites were entered in a GIS database and used to characterize the bio-geographic factors limiting the presence of sand flies. Collections were carried out with 20 x $20 \mathrm{~cm}$ sticky traps coated with castor oil according to Rioux et al. (1967) which were left in wall holes along main and side roads and recovered after 24-48 h. Additionally, CDC light traps (Hausherr's Machine Works, Toms River, NJ, USA), placed overnight outside animal shelters, were used in one instance in one collecting site. The collected sand fly specimens were identified by their morphological characteristics to species level according to Theodor (1958) and Léger et al. (1983).

\section{Canine serological survey}

At the time of the survey, the officially registered dogs in APB-ST amounted to 30,009. Of them, $7,951(26.5 \%)$ lived in the area covered by the entomological survey. Because blood collection from a random sample of owned dogs was not possible for several reasons, only dogs hosted in two kennels in the study area, i.e. the public sanitary kennel of Bolzano and a private shelter in Naturno, located about $30 \mathrm{~km}$ north-west of Bolzano, were sampled during May-June, 2008. Blood was collected into 10 $\mathrm{ml}$ tubes with silicone gel and coagulation activator, transported to the Laboratory for Animal Health in Bolzano, and centrifuged at room temperature at 2,500 $\mathrm{rpm}$ for $4 \mathrm{~min}$. At least $1 \mathrm{ml}$ serum from each sample was frozen and stored at $-20^{\circ} \mathrm{C}$. An individual standard form was completed with detailed data about each dog sampled (i.e. origin, age, sex, breed and living place). The indirect fluorescent antibody test (IFAT) was performed using L. infantum cultured promastigotes as antigen source (OIE, 2008). The 1/40 serum dilution showing fluorescent promastigotes was taken as the positive threshold antibody titre. Although a positive titre of $1 / 40$ is not indicative of an ongoing established infection, it can be an indicator for previous Leishmania exposure, and thus important to assess the circulation of the agent in the area.

\section{Awareness among local veterinarians}

A standard questionnaire, employed for surveys in the European Union (EU) 6th framework (FP6) integrated project "Emerging Diseases in a changing European eNvironment (EDEN)", was adapted for the subproject "Leishmaniasis (EDEN-LEI)" CE N. 010284-2" and translated into the main local official languages (German and Italian) and sent out by mail, including pre-stamped envelopes to ease the return of responses. Questions included the approximate number of suspected and confirmed CanL cases observed annually, frequency of observed symptoms, diagnostic and therapeutic choices, opinions about CanL trends in the area, and knowledge of prevention measures. Eligible for the questionnaire survey were veterinarians (either exclusively dealing with pets or a combination of pets and livestock) seeing at least one dog per week. In some cases veterinarians shared the same practice, had the same dogs as patients, and were asked to fill out one questionnaire in common; these groups were treated as a single entity. The individual dog data forms and the questionnaires respons- 
es were transferred into EpiData 3.1 (Lauritsen, 2000-2008).

\section{Statistical analysis}

Data were analysed using STATA.10 (Statacorp LP, College Station, TX, USA) and Excel. In the questionnaire form, pre-defined answers to the questions had been already categorised into discrete groups of variables, limiting the statistical analysis. Where applicable, the association between variables was investigated with Fisher's exact test instead of Pearson's $\chi^{2}$ since $25 \%$ of expected cell counts were $<5$.

Multivariable logistic regression was performed to test the association between selected putative risk factors and the outcome variable. Statistical significance of effect variables was tested using the likelihood ratio statistic.

\section{Results}

\section{Entomological survey}

Table 1 provides a detailed list of geographical and environmental characteristics of the sites surveyed. A total of 943 sticky traps were set during the two-period survey in $36 / 37$ sites with an average of 25.5 (5-126) traps per site. The recovery rate was $97.1 \%$. CDC traps set in the remaining site gave negative results. Among the sites monitored with sticky traps, 4/36 (11.1\%) were positive for sand flies (Table 2), with a density ranging from 0.5 to 5.8 specimens $/ \mathrm{m}^{2}$ of sticky traps. A total of 61 specimens were collected of which $55.7 \%$ were males. Two species were identified of which Sergentomyia minuta was the prevalent one $(62.3 \%)$. The other species was the competent Leishmania vector $P$. perniciosus, which was collected in two sites: Guncina and S. Genesio-b. These localities are about $1 \mathrm{~km}$ apart at altitudes of 459-487 $\mathrm{m}$ above sea level, respectively, on the porphyry walls of the mountains surrounding the northern side of Bolzano. The temperatures record- ed ranged between 20.9 and $37.8^{\circ} \mathrm{C}$, and the relative humidity differed markedly according to weather conditions between 18.3 and $57.1 \%$. In holes where the sticky traps were placed, the humidity was consistently found to be higher than the outside. The weather over most of the survey period was hot and humid during day and stormy at night.

\section{Canine serological survey}

A total of 40 sera were collected for Leishmania serology from 33 out of 40 dogs hosted in the Bolzano kennels and from seven out of 25 dogs from the Naturno shelter. All dogs investigated were of local origin. They were housed outside at night and the mean time they had spent in the kennels/shelter was 11.3 months. None of the dogs had clinical signs or symptoms of leishmaniasis. All sera tested negative at the $1 / 40$ cut off titre.

\section{Veterinary questionnaire survey}

The number of veterinarians eligible for the survey was $48(25.9 \%$ of the total numbers officially registered by the Professional Veterinary Board). Out of these, 40 veterinarians returned the questionnaire, thus the survey response rate was $83.3 \%$. The surveyed veterinarians came from the southern area of APB-ST comprising the main town of Bolzano $(23,57.5 \%)$, as well as from the western $(10,25 \%)$ and north-eastern area $(7,17.5 \%)$. The majority of them were exclusively specialised in pet animal care $(31,77 \%)$ and the range of dogs visited weekly was 11-20 or more in most of the cases $(26,65 \%)$.

Table 3 summarizes the relevant results. Veterinarians reported between 1 and 5 confirmed CanL cases annually, which were considered as imported from endemic Italian and foreign regions. The most popular diagnostic approach was serological (ELISA or IFAT); for therapy, meglumine antimoniate in combination with allopurinol was used.

The veterinarians judged the local epidemiological situation as stable but with the possibility of an 


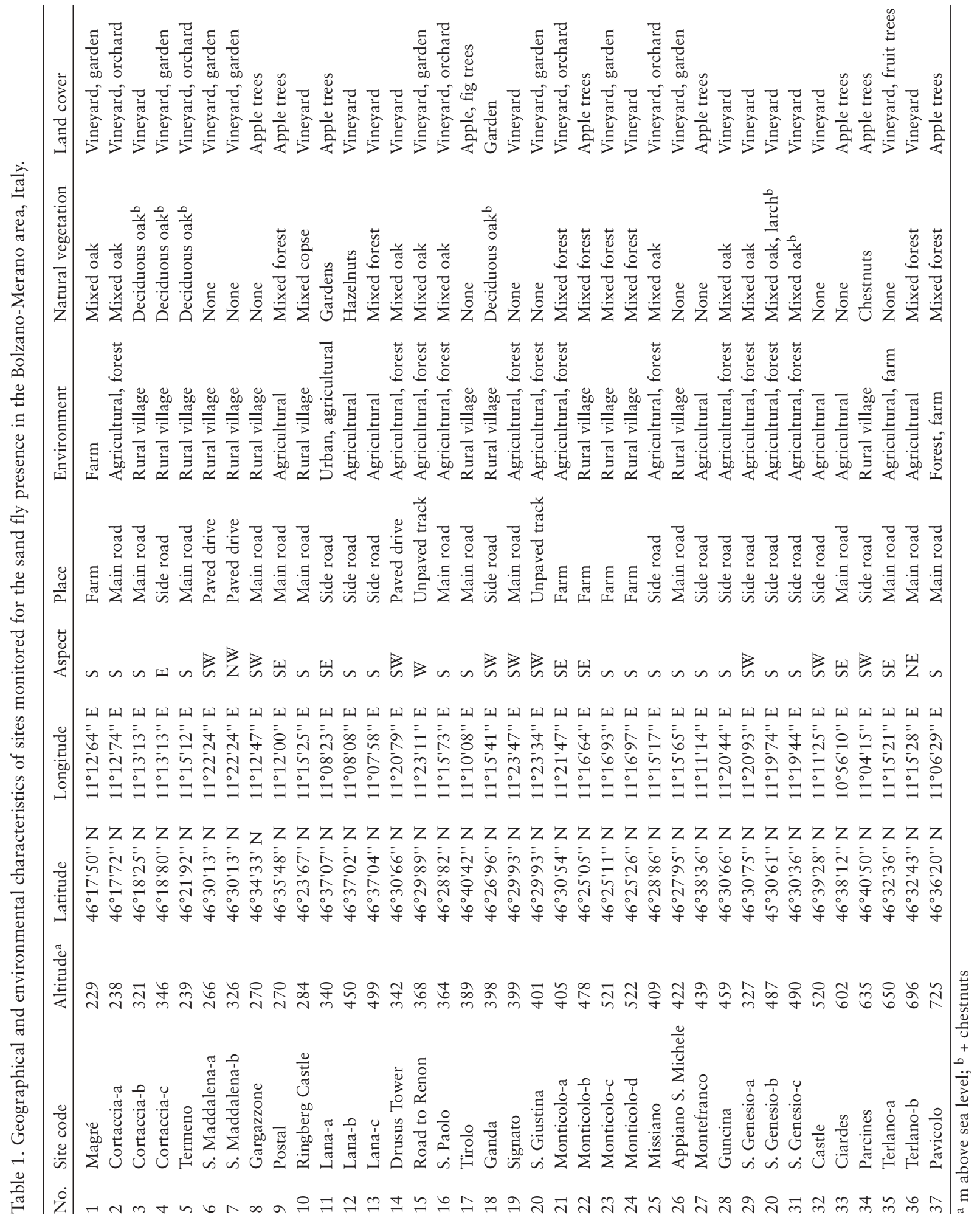


Table 2. Cumulative entomological data observed during the sand fly season 2008 in Bolzano-Merano area.

\begin{tabular}{|c|c|c|c|c|c|c|}
\hline \multirow[t]{2}{*}{ Site number } & \multirow[t]{2}{*}{ Locality } & \multicolumn{3}{|c|}{ Specimens collected } & \multicolumn{2}{|c|}{ Species } \\
\hline & & July & August & Total (M\%) & P. perniciosus & S. minuta \\
\hline 10 & Ringberg Castle & 1 & 0 & $1(0.0)$ & 0 & 1 \\
\hline 30 & S. Genesio-b & 1 & 0 & $1(100.0)$ & 1 & 0 \\
\hline 28 & Guncina & 29 & 29 & $58(57.2)$ & 22 & 36 \\
\hline 36 & Terlano-b & 0 & 1 & $1(0.0)$ & 0 & 1 \\
\hline Total (\%) & & 31 & 30 & $61(55.7)$ & $23(37.7)$ & $38(62.3)$ \\
\hline
\end{tabular}

Table 3. Veterinary questionnaire on canine leishmaniasis: relevant results for the autonomous province of APB-STa

\begin{tabular}{|c|c|c|}
\hline \multirow{2}{*}{$\begin{array}{l}\text { Question } \\
\text { Suspected cases seen annually (range) }\end{array}$} & \multicolumn{2}{|c|}{ Multiple responses (in parenthesis, the no. of filled-in questionnaires) } \\
\hline & $1-5(24)$ & $6-10(1)$ \\
\hline Confirmed cases seen annually (range) & $1-5(15)$ & $6-10(1)$ \\
\hline New cases seen annually (range) & $1-5(11)$ & - \\
\hline Origin of infected dogs & Central-southern Italy $(25)$ & Foreign endemic countries (5) \\
\hline Frequent observed symptoms & \multicolumn{2}{|c|}{ Desquamative dermatitis, lymphadenopathy, alopecia, renal insufficiency, fever (21) } \\
\hline Most frequently diagnostic approach & \multicolumn{2}{|l|}{ Serological (IFAT, ELISA) (22) } \\
\hline Preferred therapy & \multicolumn{2}{|c|}{ Meglumine antimoniate plus allopurinol (36) } \\
\hline Opinion on current situation & Stationary $(20)$ & Increasing (12) \\
\hline Opinion on future trend & Increasing (25) & Unchanged (10) \\
\hline Recommend preventive measures & Yes (39) & No (1) \\
\hline Recommended protective + products & \multicolumn{2}{|l|}{ Spot-on, collars (39) } \\
\hline
\end{tabular}

a questionnaires from 40 out of 48 eligible veterinarians

increasing risk in the future. They were actively recommending preventive measures and the most mentioned protective products were synthetic pyretroid given as spot-on or collar formulations.

\section{Discussion}

The entomological survey carried out in summer 2008 in APB-ST showed the presence of four sites positive for phlebotomines, two of which yielded specimens of $P$. perniciosus. This is the first record of phlebotomine presence in South Tyrol. The altitude range of positive sites, between 293 and $696 \mathrm{~m}$ above sea level, as well as the sand fly densities recorded (0.5-5.8 specimens $/ \mathrm{m}^{2}$ of sticky traps) were comparable to those from recent surveys carried out in neighbouring regions of Italy found endemic for CanL (Ferrarese and Maroli, 2002; Ferrarese et al.,
2004; Maroli et al., 2006a,b; Cassini et al., 2007) (Table 4).

P. perniciosus is the most widespread VL vector in Italy, present in relatively high densities in subAlpine territories of six northern continental regions of Italy (Maroli et al., 2008). The first finding of this species in an Italian Alpine region, in a setting of unstable autochthonous CanL, was reported from Aosta valley, in western Alps at a lower latitude than our study site $\left(45.4^{\circ} \mathrm{N}, 7.20^{\circ} \mathrm{E}\right.$ ) (Ferroglio et al., 2005). P. perniciosus exhibits an opportunistic feeding behaviour, taking blood meals from a range of hosts (De Colmenares et al., 1995; Bongiorno et al., 2003; Rossi et al., 2008), although dogs might be a favourite one (Schrey et al., 1989). All the surveyed sites were relatively close to human settlements and since sticky traps do not permit species selection (Maroli et al., 1994), the findings might 
Table 4. Summary of most recent sand fly collections in north-eastern sub-Alpine areas of Italy and comparison with data from present study.

\begin{tabular}{|c|c|c|c|c|c|c|c|}
\hline \multirow[t]{2}{*}{ Region (reference) } & \multirow[t]{2}{*}{$\begin{array}{l}\text { No. of sand flies } \\
\text { (collection year) }\end{array}$} & \multicolumn{2}{|c|}{$\begin{array}{c}\text { Sand fly density } \\
\text { (specimens } / \mathrm{m}^{2} \text { sticky trap) }\end{array}$} & \multicolumn{4}{|c|}{ Species } \\
\hline & & $\begin{array}{l}\text { No. } \\
\text { of traps }\end{array}$ & $\begin{array}{c}\text { Range } \\
\text { by positive site }\end{array}$ & $\begin{array}{c}\text { P. perniciosus } \\
(\%)\end{array}$ & $\begin{array}{c}\text { P. neglectus } \\
(\%)\end{array}$ & $\begin{array}{c}\text { P. mascittii } \\
(\%)\end{array}$ & $\begin{array}{l}\text { S. minuta } \\
(\%)\end{array}$ \\
\hline \multicolumn{8}{|l|}{ Trentino } \\
\hline Ferrarese and Maroli, 2002 & $19(2001)$ & 366 & $1.2-8.3$ & $32(50.0)$ & $25(39.1)$ & 0 & $7(10.9)$ \\
\hline Ferrarese et al., 2004 & $47(2004)$ & 156 & $1.3-6.2$ & & & & \\
\hline \multicolumn{8}{|l|}{ Veneto } \\
\hline \multirow[t]{2}{*}{ Cassini et al., 2007b } & $45(2005)$ & 309 & $0.2-2.3$ & $117(76.9)$ & $18(11.9)$ & 0 & $8(5.2)$ \\
\hline & 107 (2006) & 524 & $0.1-6.8$ & & & & \\
\hline \multicolumn{8}{|l|}{ Friuli Venezia-Giulia } \\
\hline \multirow[t]{2}{*}{ Cassini et al., $2007^{c}$} & $9(2005)$ & 397 & $0.1-0.9$ & $51(89.4)$ & $4(7.0)$ & 0 & 0 \\
\hline & $48(2006)$ & 720 & $0.1-1.6$ & & & & \\
\hline \multicolumn{8}{|l|}{ Lombardy } \\
\hline Maroli et al., 2006a & $230(2005)$ & 1113 & $0.3-24.5$ & $22(9.5)$ & $66(28.7)$ & $22(9.5)$ & $120(52.1)$ \\
\hline \multicolumn{8}{|l|}{$A P B-S T$} \\
\hline Present study & $61(2008)$ & 943 & $0.5-5.8$ & $23(37.7)$ & 0 & 0 & $38(62.3)$ \\
\hline
\end{tabular}

reflect habitat preferences. It is known that $P$. perniciosus prefers sub-humid and humid bioclimates (Rioux et al., 1984) and it is deemed to be ubiquitous in domestic, peri-domestic and sylvatic environments. The site with the highest sand fly density was relatively sheltered, warm, and almost undisturbed by stormy weather conditions at nights. Sand flies were recovered in natural surroundings, in crevices and holes of old stone walls covered with plants. The Mediterranean-like environmental conditions and vegetation, i.e. cypresses, palms, magnolias, agaves, arbutus and the porphyry rock walls of the mountain, seem to offer a suitable shelter and over-wintering places for sand flies.

P. perniciosus normally shares breeding sites with other phlebotomine species (Bettini et al., 1986). In neighbouring sub-Alpine territories, a second relevant VL vector, $P$. neglectus, was usually co-found in relatively high densities (Ferrarese and Maroli, 2002; Maroli et al., 2002, 2006a,b; Ferrarese et al., 2004; Ferroglio et al., 2005) (Table 4). This species, however, was not collected in our study area. As regards $S$. minuta, it is not considered a competent Leishmania vector species, however it is often associated with epidemiologically relevant phlebotomines and may have a role in the transmission of Toscana Virus (TOSV, Bunyaviridae) (Charrel et al., 2006).

Sand flies might either have colonised the APB-ST territory spontaneously from southern Italian regions, and/or might have been transported unintentionally by people from areas with high sand fly density, as already hypothesized for north-western Italy (Ferroglio et al., 2005). This seems realistic since the Adige valley is one of the main international cross paths from northern to southern Europe, with intense transit, particularly during the summer season.

South Tyrol is at the most extreme geographical border of the north-eastern CanL diffusion in Italy and the negative results of our serological screening are consistent with an expected low or nil infection 
prevalence in the local dog population. Differently from several sanitary kennels in northern Italy which host dogs from other regions, Bolzano kennels accepts primarily local animals. Apart from two young dogs ( $<1$ year), which could thus not be exposed to previous infection transmission seasons, most were of an age (6 years on average) at which Leishmania infection is usually detected in endemic zones (Trotz-Williams and Gradoni, 2003; Miranda et al., 2007). Many dogs had spent a relatively long time in the kennels (mean 11.3 months), with no recent travel history to other regions or countries.

The collected data are insufficient for establishing the undisputed absence of autochthonous CanL, considering that the dog sample was small and biased, and thus cannot be considered representative of the study area population. Neighbouring regions such as Veneto and Friuli-Venezia Giulia showed a discontinuous presence of autochthonous CanL foci with an overall seroprevalence in dogs of $0.8 \%$ (out of 365 tested dogs), but sites have been detected with much higher values $(10 \%$, out of 201 tested dogs) (Cassini et al., 2007). If CanL was also occurring with a similar focal distribution in APBST, small localized foci could indeed be present. Hence, it will be necessary to confirm these negative findings through more extensive surveys using representative samples of the local dog population.

Among the 185 veterinary practitioners, only $25.9 \%$ were eligible in the study area and most of them participated in the survey. Most of those responding were specialised in pet animals and constituted an experienced information source. In general, veterinarians' attitude towards preventive measures and education of dog owners is positive and they are well informed and aware of CanL, although they estimated the current risk of CanL in the study area to be low. In areas of new endemicity, infections are probably due to importation of infected dogs (Perego et al., 2005; Spada et al., 2005; Mortarino et al., 2008). More than one third of all the veterinarians reported having seen 1-5 confirmed imported cases in the last 12 months. Thus, the prevalent opinion among veterinarians is that the chances of seeing CanL cases in the study area will increase in the future.

Different situations of VL endemicity are currently seen in countries beyond eastern Italian Alpine territories. At north, confirmed or suspected autochthonous CanL and VL cases have been reported from Germany (Gothe et al., 1997; Bogdan et al., 2001; Naucke and Schmitt, 2004; Nauke et al., 2008) and suspected in Austria in the past (Kollaritsch et al., 1989). At east, Dalmatia (Croatia) is traditionally endemic for human VL and CanL (Bosnic et al., 2006).

Up to now, temperature has been one of the main factors preventing the spread of both VL and CanL to Northern Europe (Kuhn, 1999), but the northward spread may be favoured by global warming (KillickKendrick, 1996). In South Tyrol hypothetical local parasite transmission seems difficult; the main sand fly season is probably too short (July-September), limited by unfavourable weather conditions, like in other northern areas (Bongiorno et al., 2003; Ferroglio et al., 2006), and phlebotomines probably occur in low densities, with discontinuous distribution. However, since temperature and relative humidity seem to affect their distribution and density (Haines et al., 2006), future developments must be monitored. Higher mean temperatures over an extended period may allow shortening of larval development and extension of the breeding season, thereby increasing the risk of exposure for susceptible hosts. The geographical distribution of vectors could therefore also change in APB-ST allowing survival in more northern sites and at higher altitudes (Rioux et al., 1997; Rhodain, 2000; Rioux and De La Rocque, 2003).

\section{Acknowledgements}

We would like to thank Dr. C. Piffer, Dr. G. Lorenzi and Dr. S. Barone of the Veterinary Services of Bolzano for their collaboration in gathering data on the dog population in the area under study and Dr. K. Mair of the Provincial Agriculture Department for providing information on the insecticide usage. This work was partially supported by the EU FP6 project "EDEN", CE N. 01284-2, Subproject EDEN-LEI. 


\section{References}

Bettini S, Contini C, Atzeni MC, Tocco G, 1986. Leishmaniases in Sardinia I. Observations on larval breeding site of Phlebotomus perniciosus, Phlebotomus perfiliewi and Sergentomyia minuta (Diptera: Psychodidae) in the canine leishmaniasis focus of Soleminis (Cagliari). Ann Trop Med Parasitol 80, 307-315.

Biocca E, Coluzzi A, Costantini R, 1977. Osservazioni sull'attuale distribuzione dei flebotomi italiani e su alcuni caratteri morfologici differenziali tra le specie del sottogenere Phlebotomus. Parassitologia 19, 19-37.

Bogdan C, Schönian G, Banuls A-L, Hide M, Pratlong F, Lorenz E, Röllinghoff M, Mertens R, 2001. Visceral leishmaniasis in a German child who had never entered a known endemic area: case report and review of the literaure. Clin Infect Dis 31, 302-306.

Bongiorno G, Habluetzel A, Khoury C, Maroli M, 2003. Host preferences of phlebotomine sand flies at a hypoendemic focus of canine leishmaniasis in central Italy. Acta Trop 88, 109-116.

Bongiorno G, Scortichini MG, Gradoni L, Gramiccia M, Maroli M, 2008. Environmental and climatological factors as determinants of the distribution of two Leishmania vectors, Phlebotomus perniciosus and Phlebotomus perfiliewi, in the Apennine mountains of central Italy. Parassitologia 50, 100.

Bosnic S, Gradoni L, Khoury C, Maroli M, 2006. A review of leishmaniasis in Dalmatia (Croatia) and results from recent surveys on phlebotomine sandflies in three southern counties. Acta Trop 99, 42-49.

Capelli G, Baldelli R, Ferroglio E, Genchi C, Gradoni L, Gramiccia M, Maroli M, Mortarino M, Pietrobelli M, Rossi L, Ruggiero M, 2004. Monitoraggio della leishmaniosi canina in nord Italia: aggiornamenti da un network scientifico. Parassitologia 46, 193-197.

Cassini R, Pietrobelli M, Montarsi F, Natale A, Capelli G, Beraldo P, Sinigaglia A, Moresco G, 2007. Leishmaniosi canina in Triveneto: quali novità? Prog Vet 7, 295-300.

Charrel RN, Izri A, Temmam S, De Lamballerie X, Parola P, 2006. Toscana virus RNA in Sergentomyia minuta flies. Emerg Infect Dis 12, 1299-1300.

Climate, 2008. Information on biogeography and climate in Bolzano Province. http://www.provinz.bz.it/Hydro/wetterdaten//index_d.htm; http://reports.eea.europa.eu/report _2002_0524_154909/en/alpine.pdf; http://en.wikipedia .org/wiki/Province_of_Bolzano-Bozen.

De Colmenares M, Portus M, Botet J, Dobano C, Callego M, Wolf M, Segui G, 1995. Identification of blood meals of Phlebotomus perniciosus (Diptera: Psychodidae) in Spain by competitive enzyme-linked immunoadsorbent assay biotin/avidin method. J Med Entomol 32, 229-233.

Ferrarese U, Maroli M, 2002. Ricerche sui flebotomi (Diptera, Psychodidae) in provincia di Trento. Ann Mus Civ Rovereto 18, 171-179.

Ferrarese U, Natale A, Corradi S, Maroli M, 2004. Nuovi ritrovamenti di flebotomi (Diptera, Psychodidae) nella parte meridionale del Trentino. Ann Mus Civ Rovereto 20, 341348.

Ferroglio E, Maroli M, Gastaldo S, Mignone W, Rossi L, 2005. Canine leishmaniasis, Italy. Emerg Infect Dis 11, 1618-1619.

Ferroglio E, Romano A, Passera S, D'angelo A, Guiso P, Ghiggi E, Bolla C, Trisciuoglio A, Biglino A, 2006. Dog's parasite and zoonotic risk: from old to new "emergencies" in the North-West of Italy. Parassitologia 8, 115-116.

Ferroglio E, Rossi L, Mignone W, Maroli M, 2000. Sandfly vectors investigation at an unstable focus of canine leishmaniasis in Italy (Piedmont) and the risk of permanent infection transmission. Parassitologia 42, 114.

Gabrielli GB, Zaia B, Stanzial AM, Corrocher R, 2001. Visceral leishmaniasis: a rarely diagnosed disease in northern Italy. Report of a case. Ann Ital Med Int 16, 185-191.

Gothe R, Nolte I, Kraft W, 1997. Leishmaniasis in dogs in Germany: epidemiological case analysis and alternaives to conventional causal therapy. Tierärztliche Praxis 25, 68-71.

Haines A, Kovatz R.S, Campbell-Lendrum D, Corvalan C, 2006. Climate change and human health: impacts, vulnerability, and mitigation. Lancet 367, 2101-2109.

Killick-Kendrick R, 1996. Leishmaniasis - an English disease of the future? Bull Trop Med Int Health 4, 5.

Kollaritsch H, Emminger W, Zaunschirm A, Aspöck H, 1989. Suspected autochtonous kala-azar in Austria (letter). Lancet 8643, 901-902.

Kuhn KG, 1999. Global warming and leishmaniasis in Italy. Bull Trop Med Int Health 7, 1-2.

Lauritsen JM, 2000-2008. EpiData Data Entry, Data Management and basic Statistical Analysis System. http://epidata.dk. 
Léger N, Pesson B, Madulo-Leblond G, Abonnenc E, 1983. Sur la différenciation des femelles du sous-genre Laroussius Nitzulescu, 1931 (Diptera-Phlebotomidae) de la région méditerranéenne. Ann Parasitol Hum Comp 58, 611-623.

Maroli M, Bigliocchi F, Khoury C, 1994. I flebotomi in Italia: osservazioni sulla distribuzione e sui metodi di campionamento. Parassitologia 36, 251-264.

Maroli M, Gradoni L, Khoury C, Bianchi R, Nicoli Aldini R, Gramiccia M, 2006a. Entomological survey on phlebotomine sandflies (Diptera: Psychodidae) in three subAlpine valleys of Lombardy region, northern Italy. Parassitologia 48, 159.

Maroli M, Khoury C, Bianchi R, Ferroglio E, Natale A, 2002. Recent findings of Phlebotomus neglectus Tonnoir, 1921 in Italy and its western limit distribution. Parassitologia 44, 103-109.

Maroli M, Rossi L, Baldelli R, Capelli G, Ferroglio E, Genchi C, Gramiccia M, Mortarino M, Pietrobelli M, Gradoni L, 2008. The northward spread of leishmaniasis in Italy: evidence from retrospective and ongoing studies on the canine reservoir and phlebotomine vectors. Trop Med Int Health 13, 256-264.

Maroli M, Rossi E, Rinaldi L, Musella V, Carbone S, Veneziano V, Foglia Manzillo V, Cappiello S, Oliva G, Cringoli G, Gradoni L, 2006b. An entomological and serological survey of canine leishmaniasis along the coastal and the Appenine sides of the Mt. Vesuvius (Campania region, southern Italy). Parassitologia 48, 323.

Maroli M, Sansoni L, Bigliocchi F, Khoury C, Valsecchi M, 1995. Reperimento di Phlebotomus neglectus Tonnoir 1921 (=P. major s.l.) in un focolaio di leishmaniosi nel nord Italia (Provincia di Verona). Parassitologia 37, 241-244.

Miranda S, Roura X, Picado A, Ferrer L, Ramis A, 2007. Characterization of sex, age, and breed for a population of canine leishmaniosis diseased dogs. Res Vet Sci 85, 35-38.

Mortarino M, Maroli M, Beccati M, Buttinoni D, Calzolari ML, Meroni M, Zappellini G, Bazzocchi C, Genchi C, Gradoni L, 2008. Detection of new canine leishmaniasis foci in northern Italy. Parassitologia 50, 160.

Mortarino M, Maroli M, Gradoni L, Mancianti F, Franceschi A, Bertazzoli G, Paolini M, Genchi C, 2004. A new canine leishmaniasis focus in Brescia, Northern Italy: preliminary investigation. Parassitologia 46, 53.

Natale A, Capelli G, Frangpane Di Regalbonoa, Gramiccia
M, Maroli M, Pietrobelli M, 2004. Monitoring old and new canine lesihmaniasis foci in north-eastern Italy. Parassitologia 46, 55.

Naucke TJ, Menn B, Massberg D, Lorentz S, 2008. Sandflies and leishmaniasis in Germany. Parasitol Res 103, 65-68.

Naucke TJ, Schmitt C, 2004. Is leishmaniasis becoming endemic in Germany? Int J Med Microbiol 293, 179-181.

OIE, 2008. Leishmaniosis. In: Manual of Diagnostic Tests and Vaccines for Terrestrial Animals (mammals, birds and bees), 6th edition, Office International des Epizooties, Paris, France, pp. 240-250.

Perego R, Proverbio D, Spada E, Ferro E, 2005. Canine leishmaniasis: a sero-epidemiolofical survey by indirect fluorescence antibody test (IFAT) in 313 dogs at "CanileSanitario" of Milan. Proceedings of the Congress SISVET LIX, Viareggio, Italy.

Rhodain F, 2000. Impacts sur la santé: le cas des maladies à vecteurs. Impacts potentiels du changement climatique en France au XXI siècle. Mission interministérielle de l'effet de serre. Paris, France, Ministère de l'Aménagement du Territoire et de l'Environnement.

Rioux JA, Akalay O, Périères J, Dereue J, Mahjour J, Le Houerou HN, Léger N, Desjeux P, Gallego M, Saddiki A, Barkia A, Nachi H, 1997. L' évaluation écoépidemiologique $\mathrm{du}$ "risque leishmanien" au Sahara atlantique marocain. Interet heuristique de la rélation "Phlebotomes-bioclimats". Ecole Mediterranéenne 23, 73-92.

Rioux JA, De La Rocque S, 2003. Climats, leishmanioses et trypanosomiases. Changements climatiques, maladies infectieuses et allergiques. Ann Inst Pasteur 16, 41-62.

Rioux JA, Golvan YJ, Croset H, Houin R, Juminer B, Bain O, Tour S, 1967. Ecologie des leishmanioses dans le sud de la France. 1. Les phlébotomes. Echantillonage-ethologie. Ann Parasitol Hum Comp 42, 561-603.

Rioux JA, Rispail P, Lanotte G, Lepart J, 1984. Relations phlébotomes-bioclimats en écologie des leishmanioses corollaires épidémiologiques. L'exemple du Maroc. Bull Soc Bot France 131, 549-557.

Rossi E, Bongiorno G, Ciolli E, Di Muccio T, Scalone A, Gramiccia M, Gradoni L, Maroli M, 2008. Seasonal phenology, host-blood feeding preferences and natural Leishmania infection of Phlebotomus perniciosus (Diptera, Psychodidae) in a high-endemic focus of canine leishmaniasis in Rome province, Italy. Acta Trop 105, 
158-165.

Schrey C, Alves Pires C, Macvean D, 1989. Distribution of phlebotomine sandflies and the rate of their infection with Leishmania promastigotes in the Algarve, Portugal. Med Vet Entomol 3, 125-130.

Spada E, Proverbio D, Perego R, Tranquillo V, 2005. Clinical considerations on canine leishmaniasis in non-endemic area: a retrospective clinical study in 50 dogs naturally infected by Leishmania infantum (1996-2004). Proceedings of the Congress SISVET LIX, Viareggio, Italy.

Theodor O, 1958. Psychodidae-Phlebotominae. In: Die Fliegen der Palearktischen Region, 9c, Schweiterbart'sche Verlagsbuchhandlung, Stuttgart (D), 1-55.

Tonnoir AL, 1921. Une nouvelle espéce européenne du genre Phlebotomus (Phlebotomus neglectus). Ann Soc Entomol Belgique 6, 333-335.

Trotz-Williams L, Gradoni L, 2003. Disease risks for the travelling pet: leishmaniasis. In Pract 25, 190-197. 